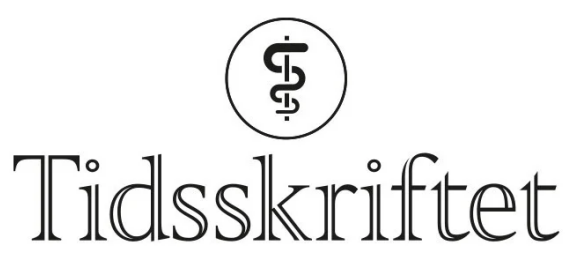

DEN NORSKE LEGEFORENING

\title{
Lite nytt i ny utgave av farmakologilærebok
}

ANMELDELSER

\section{SIGRID NARUM}

Overlege, Avdeling for farmakologi Oslo universitetssykehus

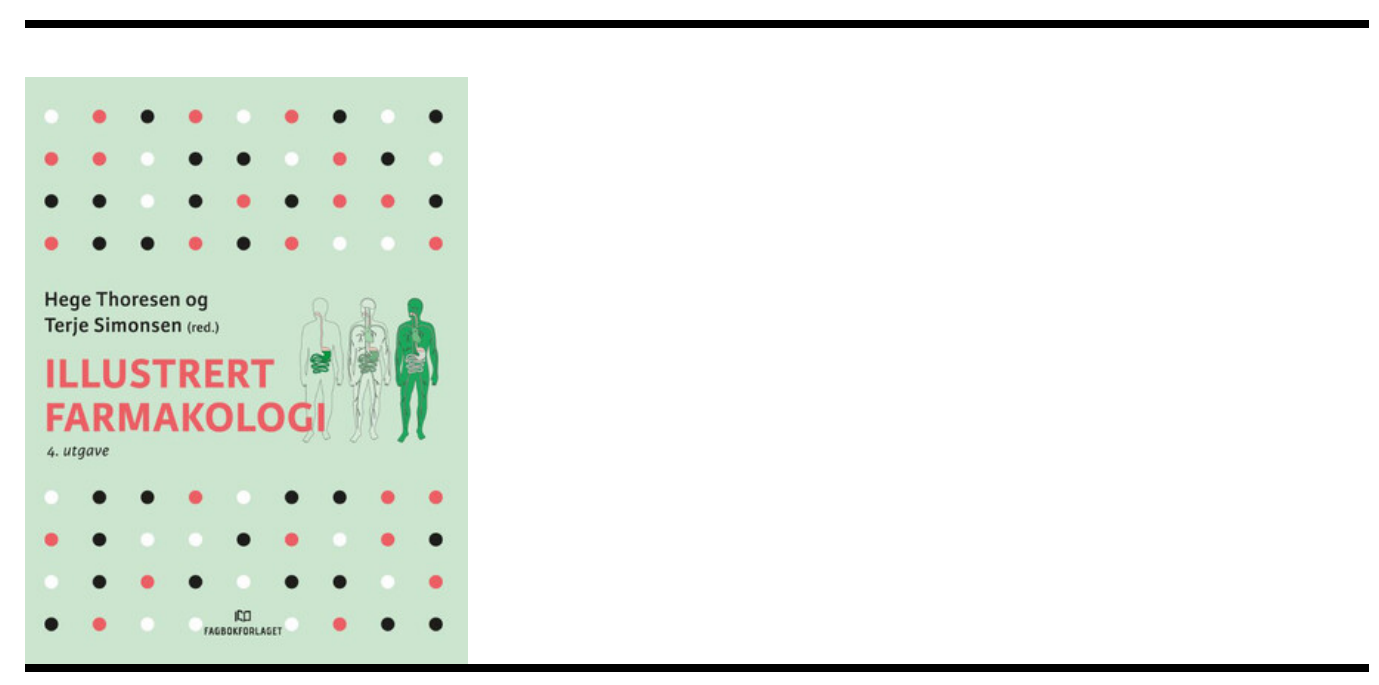

Hege Thoresen, Terje Simonsen, red.

Illustrert farmakologi

4. utg. 392 s, tab, ill. Bergen: Fagbokforlaget, 2020. Pris NOK 649

ISBN 978-82-450-3356-4

I et teori- og begrepstungt fag som farmakologi er det viktig å ha lærebøker på norsk. Den fjerde utgaven av boken Illustrert farmakologi er beregnet på studenter innen helsefag. Boken oppgis å være oppdatert og gjennomrevidert og at den bidrar til rasjonell farmakoterapi. Største endringer siden forrige utgave er at tobindsverket er slått sammen til ett bind og at boken har fått mange flere forfattere. Siden forrige utgave fra 2010/12 er boken oppdatert med nye behandlingsprinsipper, som bruk av CGRP-antagonister, PCSK9hemmere, signalhemmere i kreftbehandling og nye biologiske legemidler. 
Ellers er teksten i avsnitt etter avsnitt nærmest identisk med forrige utgave. Dette inkluderer upresise og misvisende utsagn, begreper og definisjoner. Heller ikke behandlingsanbefalingene er oppdatert. Her anbefales petidin ved fødselssmerter, og teratogen risiko ved bruk av valproat underkommuniseres. Ved revmatoid artritt poengteres at sykdomsmodifiserende antirevmatiske legemidler (DMARD) ikke bidrar til helbredelse, men ikke viktigheten av tidlig start med sykdomsmodifiserende behandling.

Boken har for øvrig en tradisjonell inndeling med de generelle farmakologikapitlene først og deretter inndeling etter organsystem. Bakerst i hvert kapittel blir hovedlinjene oppsummert i noen få setninger. Dessuten hører det med en nettressurs som har utdypende tekst og oppgaver til hvert tema. Det er mange tabeller og fargerike figurer. Dessverre er figurene lite intuitive og ofte vanskelige å forstå uten å lese teksten.

Alle legemidlene omtales kun ved generisk navn. Lengden på kapitlene varierer. Omtalen av de viktigste legemidlene inneholder egne avsnitt for virkningsmekanisme, inkludert effekt, bruksområde og bivirkninger. Andre legemidler blir mer summarisk beskrevet. Generelt er legemidlenes farepotensial mangelfullt beskrevet. Delirium, som ikke helt sjelden utløses av legemiddelbruk, er ikke nevnt. Serotonergt syndrom og malignt nevroleptikasyndrom gjenfinnes ikke i stikkordlisten. Litiumforgiftning er bare overfladisk beskrevet, og folkesykdommen demens og behandling av denne er ikke nevnt. Kapittelet om forgiftninger er tatt ut siden forrige utgave.

Ved ny utgave av en fagbok forventer man at feil fra forrige utgave er rettet opp, at begreper og definisjoner er oppdatert og i tråd med endringer i fagfeltet og at det kanskje er forsøkt å gjøre språklige forbedringer. Denne 4. utgaven oppfyller ikke forventningene.

Publisert: 25. mai 2021. Tidsskr Nor Legeforen. DOI: 10.4045/tidsskr.21.0193

(C) Tidsskrift for Den norske legeforening 2023. Lastet ned fra tidsskriftet.no 26. april 2023. 